\title{
Symposium review: Novel strategies to genetically improve mastitis resistance in dairy cattle ${ }^{1}$
}

\author{
P. Martin,${ }^{* 2}$ H. W. Barkema, $†$ L. F. Brito, ${ }^{*}$ S. G. Narayana, ${ }^{*} \dagger$ and F. Miglior ${ }^{*} \ddagger$ \\ ${ }^{*}$ Centre for Genetic Improvement of Livestock, Department of Animal Biosciences, University of Guelph, Guelph, Ontario, Canada, N1G 2W1 \\ †Department of Production Animal Health, Faculty of Veterinary Medicine, University of Calgary, 2500 University Dr. NW, Calgary, Alberta, \\ Canada, T2N 1N4 \\ ‡Canadian Dairy Network, Guelph, Ontario, Canada, N1K 1E5
}

\section{ABSTRACT}

Mastitis is a disease of major economic importance to the dairy cattle sector because of the high incidence of clinical mastitis and prevalence of subclinical mastitis and, consequently, the costs associated with treatment, production losses, and reduced animal welfare. Diseaserecording systems compiling data from a large number of farms are still not widely implemented around the world; thus, selection for mastitis resistance is often based on genetically correlated indicator traits such as somatic cell count (SCC), udder depth, and fore udder attachment. However, in the past years, several countries have initiated collection systems of clinical mastitis, based on producers recording data in most cases. The large data sets generated have enabled researchers to assess incidence of this disease and to investigate the genetic background of clinical mastitis itself, as well as its relationships with other traits of interest to the dairy industry. The genetic correlations between clinical mastitis and its previous proxies were estimated more accurately and confirmed the strong relationship of clinical mastitis with SCC and udder depth. New traits deriving from SCC were also studied, with the most relevant findings being associated with mean somatic cell score (SCS) in early lactation, standard deviation of SCS, and excessive test-day SCC pattern. Genetic correlations between clinical mastitis and other economically important traits indicated that selection for mastitis resistance would also improve resistance against other diseases and enhance both fertility and longevity. However, milk yield remains negatively correlated with clinical mastitis, emphasizing the importance

\footnotetext{
Received July 24, 2017.

Accepted November 27, 2017.

${ }^{1}$ Presented as part of the Joint ADSA/National Mastitis Council Symposium: Mastitis Control and Milk Quality Globally: Past, Present, and an Amazing Future at the ADSA Annual Meeting, Pittsburgh, Pennsylvania, June 2017.

${ }^{2}$ Corresponding author: pmarti05@uoguelph.ca
}

of including health traits in the breeding objectives to achieve genetic progress for all important traits. These studies enabled the establishment of new genetic and genomic evaluation models, which are more efficient for selection to mastitis resistance. Further studies that are potential keys for future improvement of mastitis resistance are deep investigation of the bacteriology of mastitis, identification of novel indicator traits and tools for selection, and development of a larger female reference population to improve reliability of genomic evaluations. These cutting-edge studies will result in a better understanding of the genetic background of mastitis resistance and enable a more accurate phenotyping and genetic selection to improve mastitis resistance, and consequently, animal welfare and industry profitability. Key words: mastitis, selection index, clinical mastitis, genetics

\section{INTRODUCTION}

Mastitis, inflammation of the mammary gland, is predominantly caused by intramammary invasion of pathogens in the udder. Mastitis is one of the most frequent diseases of dairy cattle, and it has important economic implications for the industry due to costs associated with reduced milk production and milk quality, premature culling of animals, veterinary treatment, and animal welfare (Lescourret and Coulon, 1994; Hogeveen et al., 2011; Siivonen et al., 2011; Heikkilä et al., 2012). A cow is considered to have clinical mastitis (CM) if it presents abnormal milk secretion from one or more quarters, with possible signs of inflammation of the udder tissues (e.g., heat, swelling, or discoloration of the skin; Kelton et al., 1998). A relatively high proportion of dairy cows have subclinical mastitis; that is, inflammation of the udder as indicated by an elevated SCC but no signs of CM. Subclinical mastitis also affects milk production and quality and is characterized by the presence of inflammatory components in the milk (Heringstad et al., 2000). 
The incidence of $\mathrm{CM}$ is high in many dairy herds around the world. For example, a mean incidence rate of $23.0 \%$ was found among a sample of Canadian herds in 2008 (Olde Riekerink et al., 2008). Furthermore, the incidence of CM has not decreased over time despite great efforts to identify management and cow factors that are associated with it (e.g., Ruud et al., 2010; Richert et al., 2013; Bates and Dohoo, 2016). This is probably partly due to the traditional intensive genetic selection for milk production traits and the genetic antagonism between milk production and mastitis resistance (Strandberg and Shook, 1989; Rupp and Boichard, 2003). In 2013, over $20 \%$ of involuntarily culled Canadian cows were culled because of problems with mastitis or high SCC (CDN, 2014).

Since the late 1970s, SCC has been widely used as a phenotypic indicator of mastitis in breeding programs around the world. The increase of milk SCC is mainly due to white blood cell recruitment in response to udder infection, and the evolution of SCC is closely linked to the magnitude of the inflammation process (Coffey et al., 1986). The SCC measurement presents a large economic advantage compared with direct bacteriological assessments. Somatic cell count is also more heritable than the direct record of CM (Rupp and Boichard, 2003) and does not require the implementation of a new system of data recording because milk samples are already routinely collected and analyzed. Furthermore, SCC is genetically both an indicator of subclinical and CM, and indirect selection is considered at least as efficient as direct selection on CM (de Jong and Lansbergen, 1996). Because the trait is not normally distributed (majority of low values), SCC is usually transformed on a logarithm scale to facilitate analysis (Ali and Shook, 1980); the SCS is the result of this logarithmic transformation. Other traits, such as udder depth or milking speed, are also associated with mastitis (Seykora and McDaniel, 1985; Sørensen et al., 2000; Rupp and Boichard, 2003) or have been shown to improve the accuracy of an index for mastitis resistance compared with an index with SCS only (Boettcher et al., 1998). Those traits, associated with SCC, were the basis of selection for mastitis resistance in most countries in past decades when no collection of CM data was implemented. The only exception is the Scandinavian countries, where health data (e.g., treatments) have been recorded by veterinarians for several decades (Heringstad et al., 2000). Health data records are useful for genetic selection; however, highly accurate breeding values are obtained only for bulls with a large number of progeny. More recently, with the development and wide uptake of genomic selection and other cutting-edge technologies in dairy cattle breeding programs, as well as the increasing demand to accelerate genetic progress for health traits, health data recording has become even more important to accelerate genetic progress for mastitis resistance. The main objectives of this review are to describe the novel phenotypic and genomic strategies to improve mastitis resistance that have been developed and implemented in the dairy industry over time, as well as to assess current studies and challenges. This review will focus on the Canadian dairy industry as an example of these advancements; however, progress in other countries will be mentioned as well.

\section{AN INCREASING COLLECTION OF PHENOTYPES}

The Nordic countries (Denmark, Finland, Norway, and Sweden) have had health recording systems for a long time. Denmark first started data collection through veterinary recording by means of a pilot study in 1966, and preliminary recording by the other Nordic countries soon followed. This led to full routine recording on a national scale implemented in Norway, Finland, Sweden, and Denmark in 1975, 1982, 1984, and 1990, respectively, with recording done by veterinarians (Heringstad et al., 2000). Following the initiative from the Nordic countries and the increasing demand for healthier cows, several countries began collecting health data.

In 2007, Canada began a nationwide effort to collect health and disease data through a project titled "National dairy cattle health and disease data management system," which aimed to provide information to dairy producers and veterinarians about herd management (Koeck et al., 2012a). Another main objective was to develop a genetic evaluation system to improve overall disease resistance in Canadian dairy cattle. As an outcome, 8 health events are voluntarily recorded by producers using on-farm management software or record books: CM, metritis, retained placenta, cystic ovaries, lameness, milk fever, ketosis, and displaced abomasum. To standardize phenotype recording, producers were provided with disease definitions adapted from Kelton et al. (1998) as a guide for identification and recording of diseases.

The data are transferred to DHI technicians at each test-day herd visit and then forwarded to the regional DHI association. Additionally, health data from Québec producers participating in the Dossier Santé Animale/ Animal Health Record program (Koeck et al., 2012a), which collects health data for herd management and veterinarian use, are also forwarded to the DHI database by the veterinarians. Once all recorded health events are processed within the national DHI database, they are transferred to the Canadian Dairy Network (CDN) for research and routine genetic evaluations. Participa- 
tion is voluntary but it quickly included (and currently includes) more than $40 \%$ of all Canadian DHI herds. In 2010 , approximately $30 \%$ of all recorded disease cases were submitted through on-farm herd management software, $30 \%$ from record books, and $40 \%$ came from the Dossier Santé Animale/Animal Health Record program (Koeck et al., 2012a). The 2016 reports indicate that $45 \%$ of the records came from on-farm management software, $18 \%$ from record books, and $37 \%$ from the Dossier Santé Animale/Animal Health Record program (Robert Moore, Valacta, Saint-Anne-de-Bellevue, QC, Canada, personal communication).

Other countries also started disease data collection. For instance, in France, data regarding CM occurrence have been collected on a small scale since 1995 through DHI organizations. In 2006, collection was generalized to the whole country and farmers are supposed to report any event of CM to the milk recording technician (Govignon-Gion et al., 2016). In 2006, a project titled "Health monitoring in cattle," based on diagnoses and strong collaboration with veterinarians, began in Austria, followed by data collection in Germany (Fuerst et al., 2011; Egger-Danner et al., 2012). In the Netherlands, where around 300 farmers have voluntarily recorded CM cases since 1998 for research purposes (Bloemhof et al., 2009), a more complete voluntary record system was set up in 2016 to use the data in the national genetic evaluation (CRV, 2016). In the United Kingdom, based on the results from Green et al. (2007), a mastitis control plan has been developed, with voluntary enrollment of farmers (http://www .mastitiscontrolplan.co.uk). Several other countries such as the United States, Spain, Australia, and the Czech Republic have also started to collect some data on selected herds and shown interest in developing a more complete recording system with the aim of improving their evaluation for mastitis resistance (Zwald et al., 2004a,b; Haile-Mariam and Goddard, 2010; Wolf et al., 2010; Pritchard et al., 2013; Pérez-Cabal and Charfeddine, 2013; Zavadilová et al., 2013).

In most of these countries (except Austria, Germany, and Czech Republic), and in contrast to the Nordic countries, CM recording is done directly by producers. The feasibility of using producer-recorded health data for genetic evaluation has been widely reported in different countries, such as the United States (Zwald et al., 2004a,b), Australia (Haile-Mariam and Goddard, 2010), United Kingdom (Kadarmideen et al., 2000; Pritchard et al., 2013), and Canada (Neuenschwander et al., 2012; Koeck et al., 2012a). In all cases, the data received from producers go through strict quality control before being used for routine genetic evaluations.

\section{KNOWLEDGE ADVANCEMENTS ON MASTITIS AND GENETICALLY CORRELATED TRAITS}

Mastitis has been an issue for the dairy industry for a long time; however, most studies have been based on a limited number of farms or animals (e.g., Sargeant et al., 1998; van Dorp et al., 1999; McLaren et al., 2006; Olde Riekerink et al., 2008; Reyher et al., 2011). As the current phenotyping system improves, it reaches a much larger number of farms and animals, wider and more diverse, and provides a better overview of the dairy cattle health situation. The accumulation of a large amount of data also enables estimation of more accurate genetic parameters and breeding values.

\section{Clinical Mastitis Incidence}

Clinical mastitis is the most frequently occurring disease in dairy cattle, with major economic, hygienic, and welfare implications. In Canada, using the new phenotyping system, the lactational incidence of CM was estimated to be $12.9,18.6$, and $22.2 \%$ in first, second, and third and later lactations, respectively (CDN, 2013). These results are consistent with other reports in the Canadian literature. For instance, Sargeant et al. (1998) reported a frequency of $16.5 \%$ in first-lactation cows, whereas more recent studies estimated the incidence rate of CM (averaged over all lactations) to be $22 \%$ (McLaren et al., 2006) and 23\% (Olde Riekerink et al., 2008). Koeck et al. (2012b) hypothesized that the small difference observed between results from the national recording system and previous studies may be due to a slight underreporting of $\mathrm{CM}$ cases from breeders in the voluntarily national recording system compared with previous studies that were based on a limited number of herds with a very important focus on health recording. This highlighted the need to expand the producer recording system to a larger scale. Nevertheless, the estimates obtained from the Canadian farmer recording system since the start of the program are similar to those of more comprehensive studies, which indicates consistency and precision in the recording process over time and consequently on the results obtained using these data.

In other countries, the incidence of CM is generally in the same range, with variation between lactations, breeds, and area. Kelton et al. (1998) reported a median incidence of $14.2 \%$ based on a literature review of 62 citations. Zwald et al. (2004a) reported a lactational incidence rate of CM of $20 \%$ in the United States (over all lactations). Negussie et al. (2010) reported that cows in the Nordic countries have a CM incidence of 
$13 \%$ in early first lactation ( -15 to $50 \mathrm{~d}$ after calving), $12 \%$ in later first lactation (51 to $300 \mathrm{~d}$ after calving), and 21 and $26 \%$, respectively, in the first half of lactations 2 and 3 ( -15 to $150 \mathrm{~d}$ after calving). In the UK, with a 305-d lactation base, Mrode et al. (2012) observed a frequency of 14,20 , and $25 \%$ in first, second, and third lactations, respectively, and Pritchard et al. (2013), from the same type of data, reported similar estimates 1 yr later $(14,21$, and $26 \%$ in first, second, and third lactations, respectively). In France, mean incidences of 10,13 , and $14 \%$ were observed in the 3 main dairy breeds (Montbéliarde, Normande, and Holstein, respectively), from a base of 0 to $150 \mathrm{~d}$ after calving, averaged over the first 3 lactations (Govignon-Gion et al., 2012). In Austria, in all breeds together, 13.5, 14.3 , and $17.0 \%$ of the cows (all lactations considered) were recorded with $\mathrm{CM}$ in 2010 in 3 data sets based on different registration methods: recorded by employees of performance-recording organizations, records considered for the genetic evaluation, or recorded by veterinarians (Egger-Danner et al., 2012).

As previously mentioned, Austria, where recording is based on diagnosis by veterinarians, has a different approach from the other countries that are mostly based on producer records. However, even between different producer-recording systems, large differences exist. In the previously cited manuscripts (Zwald et al., 2004a; Govignon-Gion et al., 2012; Mrode et al., 2012), the UK data came from records made by producers on a voluntary basis as part of routine milk recording system (such as in Canada), whereas in France (since 2006), farmers are supposed to report any event of CM to the milk recording technician, and the US data (Zwald et al., 2004a) come from 2 groups of herds enrolled in specific programs of data recording. Despite the differences in the recording systems among countries, the incidence of $\mathrm{CM}$ remains in the same range, showing that the recording system likely does not significantly influence the results, especially after a strict data quality control.

In Canada, for first-parity Holstein cows, over onethird $(\sim 35 \%)$ of $\mathrm{CM}$ cases occurred in the first month of lactation, as did the majority of cases of displaced abomasum, ketosis, retained placenta, and metritis (Koeck et al., 2012a). The highest incidence of diseases in the first month of lactation is in agreement with previous Dutch reports (Barkema et al., 1998) as well as reports from other countries (e.g., Zwald et al., 2004a; Egger-Danner et al., 2012). This phenomenon can be explained by the high physiological demands that cows face in this period, which include onset of lactation, alterations in immune mechanism, and increased lipid metabolism (Sordillo et al., 2009).

\section{Heritability Estimates}

Despite the implementation of improved management practices in dairy cattle production systems, CM still occurs in most dairy herds. Selective breeding for enhanced mastitis resistance may provide the means to further control the disease, and the success of genetic selection for this trait will depend on its heritability estimate and genetic variability. The heritability for $\mathrm{CM}$ in first lactation was estimated with a linear model at 0.02 in Canada (Koeck et al., 2012a), and re-estimated a year later to be 0.03 and 0.05 in first and later lactations, respectively (Jamrozik et al., 2013). This is consistent with previous studies based on linear models reporting heritability estimates of CM ranging from 0.001 to 0.06 , with most values being between 0.02 and 0.03 (Heringstad et al., 2000). This is also consistent with more recent studies, as summarized in Table 1. Heritability of CM is low and is lower than the heritability for SCS, which has been estimated by the Canadian Dairy Network as 0.18 (CDN, 2016).

From the studies presented in Table 1, in which all recorded $\mathrm{CM}$ are on a binary basis $(0 / 1)$, all results except 3 were obtained using a linear model. A threshold model, which accounts for the binary nature of CM and the non-normal distribution of the trait, might be regarded as more adequate in theory (Gianola, 1982). However, various studies have found that threshold models did not improve the goodness of fit or the predictive ability compared with linear models (Negussie et al., 2008a; Koeck et al., 2010a; Neuenschwander, 2010; Govignon-Gion et al., 2012). Given that, most studies on CM used a linear model, especially for computing reasons (e.g., Govignon-Gion et al., 2012) or to maintain homogeneity in the way the different traits are analyzed (Pritchard et al., 2013).

Genetic correlation between $\mathrm{CM}$ in first and in later lactations reported in Canada is moderate at 0.59 (Jamrozik et al., 2013), which indicates that they might be different traits with different sets of genes controlling their expression; therefore, it is important to include both traits separately in selection indices. This measurement is slightly different from what is reported in the literature: Jamrozik et al. (2013) compared first and later lactations, whereas other studies usually compared lactations 1 and 2, lactations 2 and 3, and lactations 1 and 3 (Carlén et al., 2004; Bloemhof et al., 2009; Mrode et al., 2012; Pritchard et al., 2013). The correlation between CM in lactations 2 and 3 is always very high (approximately 0.9 ), whereas the correlation between lactations 1 and 3 is the lowest (ranging from 0.48 to 0.70$)$. The estimated correlation between lacta- 
Table 1. Heritability estimates for clinical mastitis (presence/absence trait) in studies from 2003 to 2015 (ordered chronologically)

\begin{tabular}{|c|c|c|c|c|c|}
\hline Country & Breed & $\begin{array}{l}\text { No. of } \\
\text { cows }\end{array}$ & Heritability & Comment $^{1}$ & Reference \\
\hline Denmark & Holstein & 365,136 & 0.04 & From -10 to $50 \mathrm{~d}$ & Lassen et al. (2003) \\
\hline \multirow[t]{2}{*}{ Sweden } & \multirow[t]{2}{*}{ Holstein } & 221,104 & 0.03 & L1 & \multirow[t]{2}{*}{ Carlén et al. (2004) } \\
\hline & & 59,233 & 0.01 & L3 & \\
\hline \multirow[t]{2}{*}{ United States } & \multirow[t]{2}{*}{ Holstein } & \multirow[t]{2}{*}{105,029} & 0.10 & L1, threshold model & \multirow[t]{2}{*}{ Zwald et al. (2004a) } \\
\hline & & & 0.09 & $\begin{array}{l}\text { All lactations, threshold } \\
\text { model }\end{array}$ & \\
\hline Finland & Ayrshire & 119,915 & 0.06 & Threshold model & Negussie et al. (2008a) \\
\hline \multirow[t]{3}{*}{ The Netherlands } & \multirow{3}{*}{$\begin{array}{l}\text { Holstein, Dutch Friesian, and } \\
\text { Meuse-Rhine-Yssel }\end{array}$} & \multirow[t]{3}{*}{21,064} & 0.03 & L1 & \multirow{3}{*}{ Bloemhof et al. (2009) } \\
\hline & & & 0.03 & $\mathrm{~L} 2$ & \\
\hline & & & 0.04 & L3 & \\
\hline \multirow[t]{3}{*}{ Denmark } & \multirow[t]{3}{*}{ Holstein } & \multirow[t]{3}{*}{17,500} & 0.05 & From -15 to $50 \mathrm{~d}$ L1 & \multirow[t]{3}{*}{ Negussie et al. (2010) } \\
\hline & & & 0.03 & From 51 to $300 \mathrm{~d}$ L1 & \\
\hline & & & 0.06 & From -15 to $150 \mathrm{~d}$ L2 & \\
\hline Canada & Holstein & 61,800 & 0.02 & From 0 to $305 \mathrm{~L} 1$ & Koeck et al. (2012a) \\
\hline \multirow[t]{3}{*}{$\mathrm{UK}$} & \multirow{3}{*}{ Holstein } & 67,175 & 0.05 & L1 & \multirow{3}{*}{ Mrode et al. (2012) } \\
\hline & & 30,617 & 0.07 & $\mathrm{~L} 2$ & \\
\hline & & 16,366 & 0.09 & L3 & \\
\hline \multirow[t]{2}{*}{ Canada } & \multirow[t]{2}{*}{ Holstein } & 174,142 & 0.03 & From 0 to $150 \mathrm{~d}$ L1 & \multirow[t]{2}{*}{ Jamrozik et al. (2013) } \\
\hline & & 314,253 & 0.05 & $\begin{array}{l}\text { From } 0 \text { to } 150 \mathrm{~d} \text { L2 and } \\
\text { more }\end{array}$ & \\
\hline Spain & Holstein & 9,179 & 0.04 & All lactations & $\begin{array}{l}\text { Pérez-Cabal and } \\
\text { Charfeddine (2013) }\end{array}$ \\
\hline UK & Holstein & 124,793 & 0.04 & 0 to $305 \mathrm{~d}$, all lactations & Pritchard et al. (2013) \\
\hline Czech Republic & Holstein & 10,294 & 0.09 & All lactations & Zavadilová et al. (2013) \\
\hline Austria & Fleckvieh & 66,890 & 0.06 & $\begin{array}{l}-10 \text { to } 150 \mathrm{~d}, \text { all } \\
\text { lactations }\end{array}$ & Pfeiffer et al. (2015) \\
\hline
\end{tabular}

${ }^{1}$ All models used were linear unless otherwise specified; $\mathrm{L}=$ lactation, $\mathrm{d}=$ days postpartum.

tions 1 and 2 ranged between 0.55 and 0.90 . These results confirm that $\mathrm{CM}$ in the first lactation seems to be a different trait compared with $\mathrm{CM}$ in later lactations.

The number of cases of CM per lactation was also reported in various studies, with heritability estimates ranging from 0.04 to 0.12 (Mrode et al., 2012; Pritchard et al., 2013; Pérez-Cabal and Charfeddine, 2013; Zavadilová et al., 2013). In all cases, heritability estimates for $\mathrm{CM}$ defined as a binary trait (i.e., 0 or 1 ) or as a count trait were very similar, and the high genetic correlation between the 2 traits led the authors to conclude that they were in fact the same trait (Mrode et al., 2012; Pritchard et al., 2013; Pérez-Cabal and Charfeddine, 2013; Zavadilová et al., 2013). Defining $\mathrm{CM}$ as a binary trait may result in underestimation of some cows' susceptibility to CM because there is no distinction among cows with one versus multiple cases (Zavadilová et al., 2013). However, there is no actual difference in the analyses, likely due to the low proportion of animals with more than one case of $\mathrm{CM}$ (Pritchard et al., 2013). In addition, using the count of $\mathrm{CM}$ as the main trait would be difficult because there is currently no consensus on the manner of phenotyping it (e.g., no definition on the interval between $\mathrm{CM}$ cases to be considered as 2 different cases, or when an animal is considered free of CM). Pérez-Cabal and Charfeddine (2013) considered 2 episodes of CM to be different if at least 1 wk elapsed between diagnosis dates and the treatment periods did not overlap. However, Mrode et al. (2012) and Pritchard et al. (2013) considered a new case if no CM event was recorded during the preceding $8 \mathrm{~d}$, regardless of the treatment period, whereas Zavadilová et al. (2013) defined 2 cases as different if they occurred at least $5 \mathrm{~d}$ apart of each other.

\section{Relationship Between Mastitis and Milk Production}

It is well known that milk yield is genetically unfavorably correlated with mastitis. For instance, Carlén et al. (2004) found that the genetic correlation between $\mathrm{CM}$ and milk yield was $0.32( \pm 0.06)$ in first lactation, $0.45( \pm 0.11)$ in second lactation, and $0.26( \pm 0.20)$ in third lactation. In addition, those authors reported unfavorable positive genetic correlations between CM and fat or protein yield. Koeck et al. (2014) reported a genetic correlation of 0.40 between milk yield and 
CM. This is slightly higher than that of recent reports from other countries, which mostly ranged from 0.26 to 0.34 (Govignon-Gion et al., 2012; Pritchard et al., 2013; Pérez-Cabal and Charfeddine, 2013; Zavadilová et al., 2013).

Milk yield during the lactation is negatively affected by CM (Gröhn et al., 2004; Hagnestam et al., 2007; Koeck et al., 2014). However, genetic parameter estimates were calculated based on average milk yield over the lactation, and both SCS and milk production traits vary with stage of lactation. In the past years, several studies applied random regression models to investigate genetic relationships between $\mathrm{CM}$ and milk yield or SCS throughout lactation (e.g., Negussie et al., 2008b, 2010; Mrode et al., 2012; Gernand and König, 2014; Costa et al., 2015). The relationship between CM and milk yield throughout lactation was also studied in the Canadian dairy cattle population (Koeck et al., 2014). Those authors found no difference between estimates from the beginning and the end of lactation although there was a trend for higher correlation around the peak milk yield at 50 to 100 DIM. However, Negussie et al. (2008b) obtained the strongest genetic correlation estimates between milk yield and CM at 30 DIM and a decrease of this unfavorable correlation as lactation progressed. Their findings suggest that selection for higher lactation milk yield based on selection to increase milk yield in early lactation would have a more deleterious effect on genetic resistance to mastitis than selection for higher yield in late lactation.

\section{Association Between Clinical Mastitis and Other Traits}

Advancements in phenotyping have enabled the estimation of correlation between CM and other economically important traits. They also enabled the calculation of an accurate estimation between CM and the proxy traits that were used to select against mastitis, as well as the discovery of new proxy traits (e.g., Kadarmideen et al., 2000; Govignon-Gion et al., 2012; Koeck et al., 2012b).

The genetic correlation between $\mathrm{CM}$ and SCS was confirmed as positive and very high, ranging from 0.59 to 0.85 with all estimates for the Holstein breed being $>0.70$ (Kadarmideen and Pryce, 2001; Carlén et al., 2004; Gernand et al., 2012; Govignon-Gion et al., 2012; Pérez-Cabal and Charfeddine, 2013; Zavadilová et al., 2013). As SCC is predominantly affected by CM caused by gram-positive bacteria such as Staphylococcus aure$u s$, and less so by CM caused by gram-negative bacteria like Escherichia coli, the strength of genetic correlation between CM and SCS will depend on the distribution of pathogens causing $\mathrm{CM}$ in a population. The incidence of gram-negative CM is higher in herds with low bulk milk SCC, whereas the incidence of gram-positive CM is higher in high bulk milk SCC herds (Barkema et al., 1998; Olde Riekerink et al., 2008). The genetic correlation between CM and SCS will therefore be highest in herds and countries with a higher average SCC. Clinical mastitis is also unfavorably and negatively genetically correlated with most of the udder traits, especially udder depth, with a genetic correlation between -0.30 and 0.36 (Zwald et al., 2004a; Fuerst et al., 2011; GovignonGion et al., 2012; Koeck et al., 2012c; Pérez-Cabal and Charfeddine, 2013). The genetic correlation estimated for CM with milking speed in recent articles shows that animals with high milking speed are genetically more susceptible to have CM (Govignon-Gion et al., 2012; Pérez-Cabal and Charfeddine, 2013). However, there also is some evidence that animals with a low milking speed may be more susceptible to CM (Lund et al., 1994; Rupp and Boichard, 2003), indicating a possible nonlinear relationship between milking speed and CM. This hypothesis was reinforced by Samoré and Groen (2006), who found a nonlinear relationship between EBV for SCS and milking speed. However, further investigation is needed on this point. Regarding BCS, which has been recorded in Canada since 2006, animals with a higher BCS during lactation have fewer disease cases, particularly for ketosis, displaced abomasum, CM, and metritis (Koeck et al., 2012d) and lameness (Solano et al., 2015). The correlation of CM with BCS was estimated to be around $-0.35( \pm 0.10)$ and was re-estimated in the following year to be $-0.34( \pm 0.07)$ in first lactation and $-0.23( \pm 0.07)$ in later lactations (Jamrozik et al., 2013), which is in agreement with other reports (Lassen et al., 2003; Dechow et al., 2004; Govignon-Gion et al., 2012). Additionally, CM is negatively correlated with fertility and longevity (Zwald et al., 2004a; Holtsmark et al., 2008; Fuerst et al., 2011; Govignon-Gion et al., 2012; Koeck et al., 2012a; PérezCabal and Charfeddine, 2013; Pfeiffer et al., 2015), suggesting that selection for mastitis resistance would also improve those traits.

The Canadian national dairy cattle health and management system also enabled the calculation of correlations between CM and other diseases (Koeck et al., 2012a). Whereas phenotypic correlations between CM and other diseases were very low (between 0.01 and 0.02 ), genetic correlations were moderate (from 0.19 to 0.49 ). This indicates, in accordance with studies from other countries, that genetic selection for mastitis resistance will lead to indirect and favorable genetic progress for resistance to other diseases (Hansen et al., 2002; Lassen et al., 2003; Zwald et al., 2004b; Heringstad et al., 2007; Pfeiffer et al., 2015). De La Paz (2008) reported that cows with both high antibody and cell- 
mediated immune responses had decreased incidence for several diseases, including mastitis, ketosis, metritis, and retained placenta, compared with cows identified as low responders. Thompson-Crispi et al. (2013) reported that, in Canadian Holstein cows, natural antibodies were associated with a decreased risk for CM. Moderate and favorable genetic correlations have also been reported between non-hygiene-related hoof diseases and CM (Buch et al., 2011).

\section{SCC Traits to Predict Mastitis More Efficiently}

As previously mentioned, SCS is the predictor trait usually used in selection for mastitis resistance, in addition to some morphological traits that are also correlated with mastitis. Lactational mean SCS and test-day SCS are the 2 most commonly used indicator traits of mastitis resistance. Recently, various studies have investigated other traits derived from SCC and suggested that some of them may be alternatives to improve genetic evaluations for mastitis resistance. Green et al. (2004) analyzed the distribution pattern of test-day SCC and reported that using measures of variation (e.g., SD of SCC) and maximum cow SCC would enhance the accuracy of predicting CM compared with mean SCC. de Haas et al. (2008) observed that considering excessive test-day SCC and peak patterns described the dynamic nature of a mastitis more accurately. Urioste et al. (2010) identified the number of days of increased SCC during lactation as another promising indicator trait to select for mastitis resistance in dairy cattle. Koeck et al. (2012b) studied the feasibility of using the following alternative SCC traits as indicators of mastitis: mean SCS from different periods in the lactation, maximum SCS, SD of SCS, excessive test-day SCC, and peak pattern of test-day records. The heritabilities of mean SCS in both early and late lactation were estimated at 0.11 , whereas the heritabilities of various patterns of SCC ranged from 0.01 to 0.07 (Koeck et al., 2012b). The genetic correlation between mean SCS and CM was 0.69 and 0.68 in early and late lactation, respectively. High genetic correlations were observed between $\mathrm{CM}$ and different SCC patterns (0.82 to 0.91). These results are in the range of what was previously estimated in other populations (Heringstad et al., 2006; de Haas et al., 2008; Sørensen et al., 2009; Koeck et al., 2010b; Urioste et al., 2012). Considering these genetic parameters and after testing multiple linear regression analyses, the authors concluded that SCS in early lactation, SD of SCS, and excessive test-day SCC pattern (at least one SCC test-day above 500,000 cells $/ \mathrm{mL}$ ) were the best predictors of breeding value for mastitis resistance (Koeck et al., 2012b). These variables explained approximately $41 \%$ of the total variation in relative breeding values for mastitis resistance, whereas mean SCS in early and late lactation together explained only $25 \%$ of the total variation. These findings indicate the advantages of including these indicator traits in the routine genetic evaluations.

\section{NEW MODELS FOR BETTER SELECTION OF MASTITIS RESISTANCE}

Research developed over time and phenotyping efforts enabled the implementation of genetic selection for mastitis resistance in several countries. In the Nordic countries, Norway was the first to evaluate breeding values for mastitis in 1978, followed by Sweden, Finland, and Denmark in 1984, 1986, and 1992, respectively (Heringstad et al., 2000). The French genetic evaluation for CM officially started in 2010 (Govignon-Gion et al., 2016), and Austria and Germany implemented routine genetic evaluations for direct health traits in the same year (Fuerst et al., 2011; Egger-Danner et al., 2012). The Netherlands and Great Britain have also added direct measure of $\mathrm{CM}$ in their evaluation for mastitis resistance in 2016 and 2017, respectively (Interbull, 2016 and Interbull, 2017a, respectively).

In Canada, the official genetic evaluation for mastitis resistance was released in 2014 (CDN, 2014). First, Koeck et al. (2012c) evaluated different models to identify the best combination of indicator traits to explain the genetic variation in mastitis resistance. They concluded that $72 \%$ of the genetic variation in mastitis resistance was explained by a model including mean SCS in early lactation, udder depth, fore udder attachment, the SD of SCS, presence or absence of excessive testday ( $\mathrm{SCC}>500,000$ cells $/ \mathrm{mL}$ at least in one test-day) and BCS. In comparison, a model including only mean SCS, udder depth, and fore udder attachment, as used previously, explained only $46 \%$ of the genetic variation in mastitis resistance.

The mastitis index implemented in the Canadian dairy industry is described by Jamrozik et al. (2013). In brief, it includes 11 traits: CM case in first lactation, mean SCS in early first lactation, SD of SCS in first lactation, excessive test-day SCC in first lactation, plus the same 4 traits but in second or later lactation, and 3 type/conformation traits in first lactation only (fore udder attachment, udder depth, and BCS). Historical data for SCS and type traits are included in the model and allow a slight increase in the reliability of breeding value predictions, especially for sires with a low number of daughters. By including predictor traits in multiple-trait evaluations, EBV reliability increased by 22 points. Furthermore, using genomics, reliability increased by 16 and 8 points for young and proven bulls, respectively (Miglior et al., 2016). The heritability of 
mastitis resistance index using the defined model has been estimated to be 0.12 (CDN, 2014). The official sire proofs for mastitis resistance have a desirable correlation of $79 \%$ with the previous proofs for SCS as well as correlations of 85 and $90 \%$ for CM in first versus later lactations, respectively.

The correlations estimated by Jamrozik et al. (2013) between relative breeding values for mastitis resistance and other traits under selection in Canada are presented in Table 2. Selection for mastitis resistance will have a positive effect on herd life and fertility traits, as well as the overall conformation of the animal, especially the udder system. The correlation between mastitis resistance and milk production traits remained negative. However, these negative correlations are lower compared with those between milk production traits and CM cases or milk production traits and SCS, as previously discussed. This suggests that selection on both milk production and mastitis resistance would be more efficient than using solely SCS or CM and would enhance the interest on that trait. Mastitis resistance was also favorably correlated with Lifetime Profit Index (LPI), the overall selection index in Canada. The Holstein breed constitutes over $90 \%$ of the Canadian dairy population and thus, the majority of mastitis records in the national recording system. Considering that, the results presented here for the Canadian data sets are for the Holstein breed. However, the new genetic evaluation has also been implemented for Ayrshire and Jersey breeds.

In 2014, the Mastitis Resistance index was introduced into the LPI; in the 2017 formula for the Holstein breed, it accounts for approximately $7 \%$ of the total weight (CDN, 2017). This is slightly lower than the Austrian

Table 2. Pearson correlation between relative breeding values of sires with at least 30 daughters for mastitis resistance in first and later lactations (from Jamrozik et al., 2013)

\begin{tabular}{lcc}
\hline & \multicolumn{2}{c}{ Mastitis resistance } \\
\cline { 2 - 3 } Trait & First lactation & Later lactations \\
\hline Lifetime Performance Index & 0.11 & 0.16 \\
Milk yield & -0.15 & -0.15 \\
Protein yield & -0.17 & -0.14 \\
Fat yield & -0.08 & 0.01 \\
Herd life & 0.44 & 0.47 \\
Direct herd life & 0.39 & 0.41 \\
SCS & -0.63 & -0.79 \\
Calving to first service & 0.24 & 0.18 \\
56-d Nonreturn rate (cows) & 0.10 & 0.13 \\
Number of services (cows) & 0.13 & 0.13 \\
First service to conception (cows) & 0.16 & 0.15 \\
Days open & 0.23 & 0.19 \\
Conformation (overall) & 0.20 & 0.12 \\
Mammary system & 0.29 & 0.15 \\
Feet and legs & 0.08 & 0.09 \\
Angularity & -0.22 & -0.17 \\
\hline
\end{tabular}

index, where the udder health index for the Fleckvieh (composed of $70 \%$ SCS and 30\% CM) represents approximately $10 \%$ of the economic weight (Fuerst-Waltl et al., 2016). In French Holsteins (Interbull, 2017b) and Norwegian Reds (Norwegian Red, 2016), the udder health index weights for $18 \%$ of the Total Merit Index.

\section{CHALLENGES AND OPPORTUNITIES FOR FUTURE IMPROVEMENTS}

Even though genetic and genomic selection have been successfully implemented in several countries, which will help increasing dairy cattle mastitis resistance, some improvements are needed in the near future.

\section{Cow Reference Population}

The size of the currently available reference population is a limitation for successful implementation of genomic selection for mastitis resistance (Miglior et al., 2016). In Canada, genomic evaluations are in place for a great variety of economically important traits for the Canadian dairy industry and are currently based on an international reference population of around 32,000 bulls. However, for mastitis resistance and other novel traits, Canada is the only country of the international partners to collect those phenotypes, and data collection began only recently. Consequently, only a small group of proven bulls exists for the current definition of mastitis resistance, and the size of the reference bull population has shrunk to less than 3,000 bulls. Such a reference population has a direct effect on the accuracy of genomic evaluations, and recent studies have suggested that the most effective way to improve the accuracy of genomic EBV for such traits would be to use a cow reference population based on animals already phenotyped (Van Grevenhof et al., 2012; Calus et al., 2013). The same studies also reported that when only a small part of the population is phenotyped and genotyped, single-step genomic evaluation methodology (Aguilar et al., 2010; Christensen and Lund, 2010) provides more accurate results. The development of such cow reference population and the switch to a singlestep genomic evaluation are 2 potential improvements that need to be further investigated.

\section{Pathogen-Specific Mastitis}

Another promising field for the improvement of mastitis resistance is the study of pathogen-specific mastitis. Mastitis can be caused by many different pathogens, changing over time and location (Heringstad et al., 2000). The consequences of infection and inflammation depend on the nature of the infecting 
species, with some pathogens causing mainly CM (e.g., Escherichia coli) or mainly subclinical mastitis (e.g., Staphylococcus aureus), whereas some others have an infection with both subclinical and clinical patterns (e.g., non-agalactiae streptococci; Schukken et al., 1997). de Haas et al. (2002) and Koeck et al. (2014) reported that $\mathrm{CM}$ caused by different pathogens affects the lactation curve for SCC in different ways. For instance, SCC is low before E. coli CM and decreases rapidly after the $\mathrm{CM}$ to a level only slightly higher than before infection. In contrast, an increase in SCC is observed before Staph. aureus CM, which suggests that the pathogen is already present and has caused subclinical mastitis before clinical symptoms are observed. In addition, SCC on average remained high after Staph. aureus CM. Several heritability estimates have been reported for the most common pathogen-specific CM (Haugaard et al., 2012), and a first economic study investigating the interest of pathogen-specific selection indices for CM has been released (Sørensen et al., 2010). However, as the price of bacteriological analyses remains relatively high, few studies that include a large number of samples have been performed and more investigation in this area is warranted. Until now, no selection program has implemented pathogen-specific selection for mastitis resistance.

\section{Heifer Mastitis}

The dairy industry has also shown specific interest in the mastitis resistance of first-lactation cows around calving, also called heifer mastitis (De Vliegher et al., 2012). Some differences are indeed observed between primiparous and multiparous animals for this disease. First, the incidence of $\mathrm{CM}$ is higher in first-lactation animals in the first few days after calving compared with later in first lactation and with later-parity cows (Barkema et al., 1998; McDougall et al., 2007a). These differences may be due to different physiological challenges faced by first-lactation cows than by older ones, as they are lactating and still growing, and to the high prevalence of IMI in heifers at calving (De Vliegher et al., 2012). In addition, the negative consequences of heifer mastitis are even higher because the animals may never express their full potential during first and subsequent lactations, which results in an increased risk of premature culling (De Vliegher et al., 2005a), loss in future milk yield, and higher risk of later CM (Coffey et al., 1986; Rupp and Boichard, 2000; De Vliegher et al., 2005b). The distribution of bacteria involved also differs between heifer mastitis and CM of older cows. In New Zealand, heifers with mastitis had a higher incidence of IMI with Streptococcus uberis and CNS and a lower incidence of Staph. aureus infections compared with older animals (McDougall et al., 2007b). For all these reasons, heifer mastitis may become a key trait in the near future.

\section{New Proxies and Tools for Selection to Improve Mastitis Resistance}

There is a need to investigate other variables and tools that could facilitate the detection and selection of cows that are more resistant to mastitis. Wagter et al. (2000) presented a quantitative approach to classify Holstein cows and heifers based on phenotypic variation of serum antibody response and to determine associations with peripartum mastitis. The results were exciting, because the authors reported heritability estimates of serum antibody response to E. coli J5 between 0.13 and 0.88 , depending upon week relative to calving. Thompson-Crispi et al. (2013) investigated genetic parameters for natural antibodies and associations with specific antibodies and mastitis in Canadian Holsteins and observed that the titer of natural IgM isotype antibodies was associated with a decreased risk for CM. Pomeroy et al. (2017) reported that the number and composition of bovine monocyte subsets before calving are related to the susceptibility to infectious disease such as mastitis and metritis within 2 wk after calving. Hovinen et al. (2016) reported that the activity of lysosomal $N$-acetyl- $\beta$-D-glucosaminidase (NAGase) in milk could be used as an accurate indicator of subclinical and CM. Cooray (1994) investigated the use of bovine myeloperoxidase (a heme protein consisting of both large and small polypeptide subunits) as an indicator of mastitis in dairy cattle and concluded that the quantitative analysis of the amount of myeloperoxidase in mastitic milk can be used to detect IMI in dairy cattle.

Damm et al. (2017) presented a novel method for routine mastitis screening called differential SCC (DSCC), which represents a combined proportion of PMNL and lymphocytes expressed as a percentage. The new Foss (Hillerød, Denmark) DSCC method allows reliable, repeatable, fast, robust, and accurate determination of both DSCC and SCC at low cost (Damm et al., 2017). However, there remains a need for further studies on the outcomes of the method. Olde Riekerink et al. (2007) analyzed samples for differential cell counting to investigate how sampling time affects the sensitivity and specificity of SCC as an indicator of IMI status, and to determine which cells are responsible for the diurnal variation in SCC. Rees et al. (2017) suggested the use of a dynamometer to objectively determine udder firmness before and after milking as a proxy for mastitis detection. Those authors concluded that udder firmness could be a useful indicator for CM. However, further research using a larger and independent data 
set is still needed. Electrical conductivity of milk has also been proposed as an indicator trait for mastitis to be potentially used for genetic selection (Hamann and Zecconi, 1998). For instance, Norberg (2005) reported that by using this trait, $81 \%$ of clinical and $45 \%$ of subclinical cases were classified correctly, suggesting good efficiency of this indicator trait, which can be obtained from automated milking systems.

Hovinen et al. (2008) reported that a thermal camera was successful in detecting the 1 to $1.5^{\circ} \mathrm{C}$ temperature change on udder skin associated with $\mathrm{CM}$ and suggested that a thermal camera mounted in a milking or feeding parlor could detect temperature changes associated with $\mathrm{CM}$ or other diseases in a dairy herd. In addition, Sathiyabarathi et al. (2016) reported that infrared thermal imaging technique could be used as a potential noninvasive, quick, cow-side diagnostic technique for screening and early detection of mastitis in Holstein crossbred cows, in which cows were monitored for body temperature (i.e., eye temperature) and udder skin surface temperature before milking.

In recent years, a wide variety of "-omics" data has been generated that has the potential to be useful in research of mastitis resistance as well. These "-omics" tools include epigenomics, transcriptomics, metatranscriptomics, proteomics, and metabolomics, as well as genomics. The review by Suravajhala et al. (2016) discusses multi-omic data integration and analysis and describes the methods and applications in animal production, health, and welfare. Over time, other technologies and proxies will be developed to assist in the identification and accurate selection of animals more resistant to mastitis.

\section{CONCLUSIONS}

The development of a national DHI system is clearly essential to the dairy cattle industry in various countries because it allowed the acquisition of direct measurement of the incidence of $\mathrm{CM}$ and enabled various novel studies. Changes in evaluation, both by including new trait components and by using genomics, have considerably improved the accuracy of the breeding value estimations and, therefore, in expected annual genetic gain. An international effort to enlarge phenotypic and genotypic data sets to improve selection for mastitis resistance is very important and will lead to healthier and more efficient dairy production in the short and long term. Cutting-edge technologies and novel proxies may play an important role in increasing the accuracy of breeding values to select for mastitis resistance in the future.

\section{ACKNOWLEDGMENTS}

We acknowledge partial funding by Agriculture and Agri-Food Canada and by additional contributions from Dairy Farmers of Canada, the Canadian Dairy Network and the Canadian Dairy Commission under the AgriScience Clusters Initiative and Alberta Milk (Edmonton, AB, Canada). Partial funding was provided by Ontario Genomics. Additionally, we gratefully acknowledge partial funding by the Efficient Dairy Genome Project, funded by Genome Canada (Ottawa, Canada), Genome Alberta (Calgary, Canada), Ontario Genomics (Toronto, Canada), Alberta Ministry of Agriculture (Edmonton, Canada), Ontario Ministry of Research and Innovation (Toronto, Canada), Ontario Ministry of Agriculture, Food and Rural Affairs (Guelph, Canada), Canadian Dairy Network (Guelph, Canada), GrowSafe Systems (Airdrie, Canada), Alberta Milk (Edmonton, Canada), Victoria Agriculture (Australia), Scotland's Rural College (Edinburgh, UK), USDA Agricultural Research Service (United States), Qualitas AG (Switzerland), and Aarhus University (Denmark).

\section{REFERENCES}

Aguilar, I., I. Misztal, D. L. Johnson, A. Legarra, S. Tsuruta, and T. J. Lawlor. 2010. Hot topic: A unified approach to utilize phenotypic, full pedigree, and genomic information for genetic evaluation of Holstein final score. J. Dairy Sci. 93:743-752. https://doi.org/10 $.3168 /$ jds.2009-2730.

Ali, A. K. A., and G. E. Shook. 1980. An optimum transformation for somatic cell concentration in milk. J. Dairy Sci. 63:487-490. https://doi.org/10.3168/jds.S0022-0302(80)82959-6.

Barkema, H. W., Y. H. Schukken, T. J. Lam, M. L. Beiboer, H. Wilmink, G. Benedictus, and A. Brand. 1998. Incidence of clinical mastitis in dairy herds grouped in three categories by bulk milk somatic cell counts. J. Dairy Sci. 81:411-419. https://doi.org/10 .3168/jds.S0022-0302(98)75591-2.

Bates, A. J., and I. Dohoo. 2016. Risk factors for peri-parturient farmer diagnosed mastitis in New Zealand dairy herds: Findings from a retrospective cohort study. Prev. Vet. Med. 127:70-76. https://doi .org/10.1016/j.prevetmed.2016.03.009.

Bloemhof, S., G. de Jong, and Y. de Haas. 2009. Genetic parameters for clinical mastitis in the first three lactations of Dutch Holstein cattle. Vet. Microbiol. 134:165-171. https://doi.org/10.1016/j vetmic.2008.09.024.

Boettcher, P. J., J. C. Dekkers, and B. W. Kolstad. 1998. Development of an udder health index for sire selection based on somatic cell score, udder conformation, and milking speed. J. Dairy Sci. 81:1157-1168. https://doi.org/10.3168/jds.S0022-0302(98)75678 -4 .

Buch, L. H., A. C. Sørensen, J. Lassen, P. Berg, J.-A. Eriksson, J. H. Jakobsen, and M. K. Sørensen. 2011. Hygiene-related and feedrelated hoof diseases show different patterns of genetic correlations to clinical mastitis and female fertility. J. Dairy Sci. 94:1540-1551. https://doi.org/10.3168/jds.2010-3137.

Calus, M. P. L., D. P. Berry, G. Banos, Y. de Haas, and R. F. Veerkamp. 2013. Genomic selection: The option for new robustness traits? Adv. Anim. Biosci. 4:618-625. https://doi.org/10.1017/ S2040470013000186.

Carlén, E., E. Strandberg, and A. Roth. 2004. Genetic parameters for clinical mastitis, somatic cell score, and production in the first 
three lactations of Swedish Holstein cows. J. Dairy Sci. 87:30623070. https://doi.org/10.3168/jds.S0022-0302(04)73439-6.

CDN. 2013. Official genetic evaluation for mastitis resistance. Accessed May 31, 2017. https://www.cdn.ca/document.php?id=333.

CDN. 2014. Mastitis resistance selection: Now a reality! Accessed May 31, 2017. https://www.cdn.ca/document.php?id=356.

CDN. 2016. Heritability estimates used for genetic evaluation in Canada. Accessed May 31, 2017. https://www.cdn.ca/document.php ?id $=460$.

CDN. 2017. Lifetime Performance Index (LPI) formula. Accessed May 31, 2017. https://www.cdn.ca/document.php?id=443.

Christensen, O. F., and M. S. Lund. 2010. Genomic prediction when some animals are not genotyped. Genet. Sel. Evol. 42:2 https://doi .org/10.1186/1297-9686-42-2.

Coffey, E. M., W. E. Vinson, and R. E. Pearson. 1986. Somatic cell counts and infection rates for cows of varying somatic cell count in initial test of first lactation. J. Dairy Sci. 69:552-555. https://doi .org/10.3168/jds.S0022-0302(86)80437-4.

Cooray, R. 1994. Use of bovine myeloperoxidase as an indicator of mastitis in dairy cattle. Vet. Microbiol. 42:317-326.

Costa, C. N., G. G. Santos, J. A. Cobuci, G. Thompson, and J. G. V. Carvalheira. 2015. Genetic parameters for test day somatic cell score in Brazilian Holstein cattle. Genet. Mol. Res. 14:1911719127. https://doi.org/10.4238/2015.December.29.21.

CRV. 2016. Breeding value Udder Health (Manual Quality, Chapter E-27). Accessed May 31, 2017. https://www.crv4all-international .com/wp-content/uploads/2016/04/E_27_apr2016_eng.pdf.

Damm, M., C. Holm, M. Blaabjerg, M. N. Bro, and D. Schwarz. 2017. Differential somatic cell count-A novel method for routine mastitis screening in the frame of Dairy Herd Improvement testing programs. J. Dairy Sci. 100:4926-4940. https://doi.org/10.3168/ jds.2016-12409.

de Haas, Y., H. W. Barkema, and R. F. Veerkamp. 2002. The effect of pathogen-specific clinical mastitis on the lactation curve for somatic cell count. J. Dairy Sci. 85:1314-1323. https://doi.org/10 .3168/jds.S0022-0302(02)74196-9.

de Haas, Y., W. Ouweltjes, J. ten Napel, J. J. Windig, and G. de Jong. 2008. Alternative somatic cell count traits as mastitis indicators for genetic selection. J. Dairy Sci. 91:2501-2511. https://doi.org/ 10.3168/jds.2007-0459.

de Jong, G., and L. M. T. E. Lansbergen. 1996. Udder health index: Selection for mastitis resistance. Proc. International workshop on genetic improvement of functional traits in cattle. Interbull Bull. $12: 42-47$

De La Paz, J. M. 2008. Using humoral and cellular response to novel antigens in periparturient dairy cows as a measure of genetic resistance. MSc Thesis. University of Florida, Gainesville.

De Vliegher, S., H. W. Barkema, G. Opsomer, A. de Kruif, and L. Duchateau. 2005a. Association between somatic cell count in early lactation and culling of dairy heifers using Cox frailty models. J. Dairy Sci. 88:560-568. https://doi.org/10.3168/jds.S0022 -0302(05)72718-1.

De Vliegher, S., H. W. Barkema, H. Stryhn, G. Opsomer, and A. de Kruif. 2005b. Impact of early lactation somatic cell count in heifers on milk yield over the first lactation. J. Dairy Sci. 88:938-947. https://doi.org/10.3168/jds.S0022-0302(05)72761-2.

De Vliegher, S., L. K. Fox, S. Piepers, S. McDougall, and H. W. Barkema. 2012. Invited review: Mastitis in dairy heifers: Nature of the disease, potential impact, prevention, and control. J. Dairy Sci. 95:1025-1040. https://doi.org/10.3168/jds.2010-4074.

Dechow, C. D., G. W. Rogers, U. Sander-Nielsen, L. Klei, T. J. Lawlor, J. S. Clay, A. E. Freeman, G. Abdel-Azim, A. Kuck, and S. Schnell. 2004. Correlations among body condition scores from various sources, dairy form, and cow health from the United States and Denmark. J. Dairy Sci. 87:3526-3533. https://doi.org/10 $.3168 / \mathrm{jds} . \mathrm{S} 0022-0302(04) 73489-\mathrm{X}$.

Egger-Danner, C., B. Fuerst-Waltl, W. Obritzhauser, C. Fuerst, H. Schwarzenbacher, B. Grassauer, M. Mayerhofer, and A. Koeck. 2012. Recording of direct health traits in Austria-Experience report with emphasis on aspects of availability for breeding purpos- es. J. Dairy Sci. 95:2765-2777. https://doi.org/10.3168/jds.2011 -4876 .

Fuerst, C., A. Koeck, C. Egger-Danner, and B. Fuerst-Waltl. 2011. Routine genetic evaluation for direct health traits in Austria and Germany. Interbull Bull. 44:210-215.

Fuerst-Waltl, B., C. Fuerst, W. Obritzhauser, and C. Egger-Danner. 2016. Sustainable breeding objectives and possible selection response: Finding the balance between economics and breeders' preferences. J. Dairy Sci. 99:9796-9809. https://doi.org/10.3168/jds .2016-11095.

Gernand, E., and S. König. 2014. Random regression test-day model for clinical mastitis: Genetic parameters, model comparison, and correlations with indicator traits. J. Dairy Sci. 97:3953-3963. https://doi.org/10.3168/jds.2013-7830.

Gernand, E., P. Rehbein, U. U. von Borstel, and S. König. 2012. Incidences of and genetic parameters for mastitis, claw disorders, and common health traits recorded in dairy cattle contract herds. J. Dairy Sci. 95:2144-2156. https://doi.org/10.3168/jds.2011-4812.

Gianola, D. 1982. Theory and analysis of threshold characters. J. Anim. Sci. 54:1079-1096. https://doi.org/10.2527/jas1982.5451079x.

Govignon-Gion, A., R. Dassonneville, G. Baloche, and V. Ducrocq. 2012. Genetic evaluation of mastitis in dairy cattle in France. Interbull Bull. 46:121-126.

Govignon-Gion, A., R. Dassonneville, G. Baloche, and V. Ducrocq. 2016. Multiple trait genetic evaluation of clinical mastitis in three dairy cattle breeds. Animal 10:558-565. https://doi.org/10.1017/ S1751731115002529.

Green, M. J., L. E. Green, Y. H. Schukken, A. J. Bradley, E. J. Peeler, H. W. Barkema, Y. de Haas, V. J. Collis, and G. F. Medley. 2004. Somatic cell count distributions during lactation predict clinical mastitis. J. Dairy Sci. 87:1256-1264. https://doi.org/10.3168/jds .S0022-0302(04)73276-2.

Green, M. J., K. A. Leach, J. Breen, L. E. Green, and A. J. Bradley. 2007. National intervention study of mastitis control in dairy herds in England and Wales. Vet. Rec. 160:287-293. https://doi.org/10 $.1136 / v r .160 .9 .287$.

Gröhn, Y. T., D. J. Wilson, R. N. González, J. A. Hertl, H. Schulte, G. Bennett, and Y. H. Schukken. 2004. Effect of pathogen-specific clinical mastitis on milk yield in dairy cows. J. Dairy Sci. 87:3358 3374. https://doi.org/10.3168/jds.S0022-0302(04)73472-4.

Hagnestam, C., U. Emanuelson, and B. Berglund. 2007. Yield losses associated with clinical mastitis occurring in different weeks of lactation. J. Dairy Sci. 90:2260-2270. https://doi.org/10.3168/jds .2006-583.

Haile-Mariam, M., and M. E. Goddard. 2010. Preliminary genetic analyses of voluntarily supplied disease data in Australian dairy herds. Anim. Prod. Sci. 50:186-192. https://doi.org/10.1071/ AN09113.

Hamann, J., and A. Zecconi. 1998. Evaluation of the electrical conductivity of milk as a mastitis indicator. IDF bulletin 334. International Dairy Federation, Brussels, Belgium.

Hansen, M., M. S. Lund, M. K. Sørensen, and L. G. Christensen. 2002 Genetic parameters of dairy character, protein yield, clinical mastitis, and other diseases in the Danish Holstein cattle. J. Dairy Sci. 85:445-452. https://doi.org/10.3168/jds.S0022-0302(02)74093-9.

Haugaard, K., B. Heringstad, and A. C. Whist. 2012. Genetic analysis of pathogen-specific clinical mastitis in Norwegian Red cows. J. Dairy Sci. 95:1545-1551. https://doi.org/10.3168/jds.2011-4522.

Heikkilä, A.-M., J. I. Nousiainen, and S. Pyörälä. 2012. Costs of clinical mastitis with special reference to premature culling. J. Dairy Sci. 95:139-150. https://doi.org/10.3168/jds.2011-4321.

Heringstad, B., D. Gianola, Y. M. Chang, J. Ødegård, and G. Klemetsdal. 2006. Genetic associations between clinical mastitis and somatic cell score in early first-lactation cows. J. Dairy Sci. 89:2236-2244. https://doi.org/10.3168/jds.S0022-0302(06)72295 -0 .

Heringstad, B., G. Klemetsdal, and J. Ruane. 2000. Selection for mastitis resistance in dairy cattle: a review with focus on the situation in the Nordic countries. Livest. Prod. Sci. 64:95-106. https://doi .org/10.1016/S0301-6226(99)00128-1. 
Heringstad, B., G. Klemetsdal, and T. Steine. 2007. Selection responses for disease resistance in two selection experiments with Norwegian red cows. J. Dairy Sci. 90:2419-2426. https://doi.org/ 10.3168/jds.2006-805.

Hogeveen, H., K. Huijps, and T. J. G. M. Lam. 2011. Economic aspects of mastitis: New developments. N. Z. Vet. J. 59:16-23. https://doi .org/10.1080/00480169.2011.547165.

Holtsmark, M., B. Heringstad, P. Madsen, and J. Ødegård. 2008. Genetic relationship between culling, milk production, fertility, and health traits in Norwegian red cows. J. Dairy Sci. 91:4006-4012. https://doi.org/10.3168/jds.2007-0816.

Hovinen, M., J. Siivonen, S. Taponen, L. Hänninen, M. Pastell, A.-M. Aisla, and S. Pyörälä. 2008. Detection of clinical mastitis with the help of a thermal camera. J. Dairy Sci. 91:4592-4598. https://doi .org $/ 10.3168 /$ jds.2008-1218.

Hovinen, M., H. Simojoki, R. Pösö, J. Suolaniemi, P. Kalmus, L. Suojala, and S. Pyörälä. 2016. N-Acetyl- $\beta$-D-glucosaminidase activity in cow milk as an indicator of mastitis. J. Dairy Res. 83:219-227. https://doi.org/10.1017/S0022029916000224.

Interbull. 2016. Accessed Dec. 2017. http://www.interbull.org/static/ web/uderdoc1604r.pdf.

Interbull. 2017a. Accessed Dec 2017. http://www.interbull.org/static/ web/uderdoc1704r.pdf.

Interbull. 2017b. Description of national genetic evaluation systems. Accessed Dec 2017. https://wiki.interbull.org/public/Nat_GE _Forms?action $=$ AttachFile\&do=get\&target $=$ FRAuh.rtf.

Jamrozik, J., A. Koeck, F. Miglior, G. Kistemaker, F. Schenkel, D. Kelton, and B. V. Doormaal. 2013. Genetic and genomic evaluation of mastitis resistance in Canada. Interbull Bull. 47:43-51.

Kadarmideen, H. N., and J. E. Pryce. 2001. Genetic and economic relationships between somatic cell count and clinical mastitis and their use in selection for mastitis resistance in dairy cattle. Anim. Sci. 73:19-28. https://doi.org/10.1017/S135772980005801X.

Kadarmideen, H. N., R. Thompson, and G. Simm. 2000. Linear and threshold model genetic parameters for disease, fertility and milk production in dairy cattle. Anim. Sci. 71:411-419. https://doi.org/ 10.1017/S1357729800055338.

Kelton, D. F., K. D. Lissemore, and R. E. Martin. 1998. Recommendations for recording and calculating the incidence of selected clinical diseases of dairy cattle. J. Dairy Sci. 81:2502-2509. https://doi .org/10.3168/jds.S0022-0302(98)70142-0.

Koeck, A., B. Heringstad, C. Egger-Danner, C. Fuerst, and B. FuerstWaltl. 2010a. Comparison of different models for genetic analysis of clinical mastitis in Austrian Fleckvieh dual-purpose cows. J. Dairy Sci. 93:4351-4358. https://doi.org/10.3168/jds.2009-2955.

Koeck, A., B. Heringstad, C. Egger-Danner, C. Fuerst, P. Winter, and B. Fuerst-Waltl. 2010b. Genetic analysis of clinical mastitis and somatic cell count traits in Austrian Fleckvieh cows. J. Dairy Sci. 93:5987-5995. https://doi.org/10.3168/jds.2010-3451.

Koeck, A., S. Loker, F. Miglior, D. F. Kelton, J. Jamrozik, and F. S. Schenkel. 2014. Genetic relationships of clinical mastitis, cystic ovaries, and lameness with milk yield and somatic cell score in first-lactation Canadian Holsteins. J. Dairy Sci. 97:5806-5813. https://doi.org/10.3168/jds.2013-7785.

Koeck, A., F. Miglior, D. F. Kelton, and F. S. Schenkel. 2012a. Health recording in Canadian Holsteins: data and genetic parameters. J. Dairy Sci. 95:4099-4108. https://doi.org/10.3168/jds.2011-5127.

Koeck, A., F. Miglior, D. F. Kelton, and F. S. Schenkel. 2012b. Alternative somatic cell count traits to improve mastitis resistance in Canadian Holsteins. J. Dairy Sci. 95:432-439. https://doi.org/10 $.3168 /$ jds.2011-4731.

Koeck, A., F. Miglior, D. F. Kelton, and F. S. Schenkel. 2012c. Short communication: Genetic parameters for mastitis and its predictors in Canadian Holsteins. J. Dairy Sci. 95:7363-7366. https://doi .org $/ 10.3168 /$ jds.2012-5648.

Koeck, A., F. Miglior, D. F. Kelton, and F. S. Schenkel. 2012d. Short communication: Genetic association of body condition score with disease resistance in first lactation Canadian Holsteins. Can. J. Anim. Sci. 92:285-289. https://doi.org/10.4141/cjas2012-047.

Lassen, J., M. Hansen, M. K. Sørensen, G. P. Aamand, L. G. Christensen, and P. Madsen. 2003. Genetic relationship between body condition score, dairy character, mastitis, and diseases other than mastitis in first-parity Danish Holstein cows. J. Dairy Sci. 86:37303735. https://doi.org/10.3168/jds.S0022-0302(03)73979-4.

Lescourret, F., and J. B. Coulon. 1994. Modeling the impact of mastitis on milk production by dairy cows. J. Dairy Sci. 77:2289-2301. https://doi.org/10.3168/jds.S0022-0302(94)77172-1.

Lund, T., F. Miglior, J. C. M. Dekkers, and E. B. Burnside. 1994. Genetic relationships between clinical mastitis, somatic cell count, and udder conformation in Danish Holsteins. Livest. Prod. Sci. 39:243-251. https://doi.org/10.1016/0301-6226(94)90203-8.

McDougall, S., K. E. Agnew, R. Cursons, X. X. Hou, and C. R. W. Compton. 2007a. Parenteral treatment of clinical mastitis with tylosin base or penethamate hydriodide in dairy cattle. J. Dairy Sci. 90:779-789. https://doi.org/10.3168/jds.S0022-0302(07)71562-X.

McDougall, S., D. G. Arthur, M. A. Bryan, J. J. Vermunt, and A. M. Weir. 2007b. Clinical and bacteriological response to treatment of clinical mastitis with one of three intramammary antibiotics. N. Z Vet. J. 55:161-170. https://doi.org/10.1080/00480169.2007.36762.

McLaren, C. J., K. D. Lissemore, T. F. Duffield, K. E. Leslie, D. F. Kelton, and B. Grexton. 2006. The relationship between herd level disease incidence and a return over feed index in Ontario dairy herds. Can. Vet. J. 47:767-773.

Miglior, F., R. Finocchiaro, F. Malchiodi, A. Fleming, L. Brito, C. F. Baes, J. Jamrozik, P. Martin, J. Chesnais, and F. S. Schenkel. 2016. Enhancing the data pipeline for novel traits in the genomic era: From farms to DHI to evaluation centres. Pages 23-29 in Proc. 40th ICAR Biennial Session, Puerto Varas, Chile. ICAR Technical Series no. 21. ICAR, Rome, Italy.

Mrode, R., T. Pritchard, M. Coffey, and E. Wall. 2012. Joint estimation of genetic parameters for test-day somatic cell count and mastitis in the United Kingdom. J. Dairy Sci. 95:4618-4628. https:// doi.org/10.3168/jds.2011-4971.

Negussie, E., M. Lidauer, E. A. Mäntysaari, I. Strandén, J. Pösö, U. S. Nielsen, K. Johansson, J.-Å. Eriksson, and G. P. Aamand. 2010. Combining test day SCS with clinical mastitis and udder type traits: A random regression model for joint genetic evaluation of udder health in Denmark, Finland and Sweden. Interbull Bull. $42: 25-32$

Negussie, E., I. Strandén, and E. A. Mäntysaari. 2008a. Genetic analysis of liability to clinical mastitis, with somatic cell score and production traits using bivariate threshold-linear and linear-linear models. Livest. Sci. 117:52-59. https://doi.org/10.1016/j.livsci 2007.11.009.

Negussie, E., I. Strandén, and E. A. Mäntysaari. 2008b. Genetic association of clinical mastitis with test-day somatic cell score and milk yield during first lactation of Finnish Ayrshire cows. J. Dairy Sci. 91:1189-1197. https://doi.org/10.3168/jds.2007-0510.

Neuenschwander, T. F.-O. 2010. Studies on disease resistance based on producer-recorded data in Canadian Holsteins. PhD Thesis. University of Guelph, Guelph, Ontario, Canada.

Neuenschwander, T. F.-O., F. Miglior, J. Jamrozik, O. Berke, D. F. Kelton, and L. R. Schaeffer. 2012. Genetic parameters for producer-recorded health data in Canadian Holstein cattle. Animal 6:571-578. https://doi.org/10.1017/S1751731111002059.

Norberg, E. 2005. Electrical conductivity of milk as a phenotypic and genetic indicator of bovine mastitis: A review. Livest. Prod. Sci. 96:129-139. https://doi.org/10.1016/j.livprodsci.2004.12.014.

Norwegian Red. 2016. Total Merit Index. Accessed Oct. 3, 2017. https://www.norwegianred.com/Start/Norwegian-Red/about -norwegian-red/Norwegian-Red-Total-Merit-Index/.

Olde Riekerink, R. G. M., H. W. Barkema, D. F. Kelton, and D. T. Scholl. 2008. Incidence rate of clinical mastitis on Canadian dairy farms. J. Dairy Sci. 91:1366-1377. https://doi.org/10.3168/ jds.2007-0757.

Olde Riekerink, R. G. M., H. W. Barkema, W. Veenstra, F. E. Berg, H. Stryhn, and R. N. Zadoks. 2007. Somatic cell count during and between milkings. J. Dairy Sci. 90:3733-3741. https://doi.org/10 $.3168 /$ jds.2007-0001.

Pérez-Cabal, M. A., and N. Charfeddine. 2013. Genetic relationship between clinical mastitis and several traits of interest in Spanish Holstein dairy cattle. Interbull Bull. 47:77-81. 
Pfeiffer, C., C. Fuerst, V. Ducrocq, and B. Fuerst-Waltl. 2015. Short communication: Genetic relationships between functional longevity and direct health traits in Austrian Fleckvieh cattle. J. Dairy Sci. 98:7380-7383. https://doi.org/10.3168/jds.2015-9632.

Pomeroy, B., A. Sipka, J. Hussen, M. Eger, Y. Schukken, and H.-J. Schuberth. 2017. Counts of bovine monocyte subsets prior to calving are predictive for postpartum occurrence of mastitis and metritis. Vet. Res. 48:13. https://doi.org/10.1186/s13567-017-0415-8.

Pritchard, T., M. Coffey, R. Mrode, and E. Wall. 2013. Genetic parameters for production, health, fertility and longevity traits in dairy cows. Animal 7:34-46. https://doi.org/10.1017/ S1751731112001401.

Rees, A., C. Fischer-Tenhagen, and W. Heuwieser. 2017. Udder firmness as a possible indicator for clinical mastitis. J. Dairy Sci 100:2170-2183. https://doi.org/10.3168/jds.2016-11940.

Reyher, K. K., S. Dufour, H. W. Barkema, L. Des Côteaux, T. J. Devries, I. R. Dohoo, G. P. Keefe, J.-P. Roy, and D. T. Scholl. 2011. The National Cohort of Dairy Farms - A data collection platform for mastitis research in Canada. J. Dairy Sci. 94:16161626. https://doi.org/10.3168/jds.2010-3180.

Richert, R. M., K. M. Cicconi, M. J. Gamroth, Y. H. Schukken, K. E. Stiglbauer, and P. L. Ruegg. 2013. Risk factors for clinical mastitis, ketosis, and pneumonia in dairy cattle on organic and small conventional farms in the United States. J. Dairy Sci. 96:4269 4285. https://doi.org/10.3168/jds.2012-5980.

Rupp, R., and D. Boichard. 2000. Relationship of early first lactation somatic cell count with risk of subsequent first clinical mastitis. Livest. Prod. Sci. 62:169-180. https://doi.org/10.1016/S0301 -6226(99)00056-1.

Rupp, R., and D. Boichard. 2003. Genetics of resistance to mastitis in dairy cattle. Vet. Res. 34:671-688. https://doi.org/10.1051/vetres: 2003020.

Ruud, L. E., K. E. Bøe, and O. Østerås. 2010. Associations of soft flooring materials in free stalls with milk yield, clinical mastitis, teat lesions, and removal of dairy cows. J. Dairy Sci. 93:1578-1586. https://doi.org/10.3168/jds.2009-2752.

Samoré, A. B., and A. F. Groen. 2006. Proposal of an udder health genetic index for the Italian Holstein Friesian based on first lactation data. Ital. J. Anim. Sci. 5:359-370.

Sargeant, J. M., H. M. Scott, K. E. Leslie, M. J. Ireland, and A. Bashiri. 1998. Clinical mastitis in dairy cattle in Ontario: frequency of occurrence and bacteriological isolates. Can. Vet. J. 39:33-38.

Sathiyabarathi, M., S. Jeyakumar, A. Manimaran, H. A. Pushpadass, M. Sivaram, K. P. Ramesha, D. N. Das, M. A. Kataktalware, G. Jayaprakash, and T. K. Patbandha. 2016. Investigation of body and udder skin surface temperature differentials as an early indicator of mastitis in Holstein Friesian crossbred cows using digital infrared thermography technique. Vet. World 9:1386-1391. https:// doi.org/10.14202/vetworld.2016.1386-1391.

Schukken, Y. H., T. J. G. M. Lam, and H. W. Barkema. 1997. Biological basis for selection on udder health traits. Interbull Bull. $15: 27-33$.

Seykora, A. J., and B. T. McDaniel. 1985. Udder and teat morphology related to mastitis resistance: a review. J. Dairy Sci. 68:2087-2093. https://doi.org/10.3168/jds.S0022-0302(85)81072-9.

Siivonen, J., S. Taponen, M. Hovinen, M. Pastell, B. J. Lensink, S. Pyörälä, and L. Hänninen. 2011. Impact of acute clinical mastitis on cow behaviour. Appl. Anim. Behav. Sci. 132:101-106. https:// doi.org/10.1016/j.applanim.2011.04.005.

Solano, L., H. W. Barkema, E. A. Pajor, S. Mason, S. J. LeBlanc, J. C. Zaffino Heyerhoff, C. G. R. Nash, D. B. Haley, E. Vasseur, D. Pellerin, J. Rushen, A. M. de Passillé, and K. Orsel. 2015. Prevalence of lameness and associated risk factors in Canadian HolsteinFriesian cows housed in freestall barns. J. Dairy Sci. 98:6978-6991. https://doi.org/10.3168/jds.2015-9652.

Sordillo, L. M., G. A. Contreras, and S. L. Aitken. 2009. Metabolic factors affecting the inflammatory response of periparturient dairy cows. Anim. Health Res. Rev. 10:53-63. https://doi.org/10.1017/ S1466252309990016.

Sørensen, L. P., T. Mark, P. Madsen, and M. S. Lund. 2009. Genetic correlations between pathogen-specific mastitis and somatic cell count in Danish Holsteins. J. Dairy Sci. 92:3457-3471. https://doi .org/10.3168/jds.2008-1870.

Sørensen, L. P., T. Mark, M. K. Sørensen, and S. Østergaard. 2010 Economic values and expected effect of selection index for pathogen-specific mastitis under Danish conditions. J. Dairy Sci. 93:358-369. https://doi.org/10.3168/jds.2009-2506.

Sørensen, M. K., J. Jensen, and L. G. Christensen. 2000. Udder conformation and mastitis resistance in Danish first-lactation cows: Heritabilities, genetic and environmental correlations. Acta $\mathrm{Ag}$ ric. Scand. A Anim. Sci. 50:72-82. https://doi.org/10.1080/ 09064700412331312311.

Strandberg, E., and G. E. Shook. 1989. Genetic and economic responses to breeding programs that consider mastitis. J. Dairy Sci 72:2136-2142. https://doi.org/10.3168/jds.S0022-0302(89)79338 -3 .

Suravajhala, P., L. J. A. Kogelman, and H. N. Kadarmideen. 2016. Multi-omic data integration and analysis using systems genomics approaches: Methods and applications in animal production, health and welfare. Genet. Sel. Evol. 48:38. https://doi.org/10 $.1186 / \mathrm{s} 12711-016-0217-\mathrm{x}$.

Thompson-Crispi, K. A., F. Miglior, and B. A. Mallard. 2013. Genetic parameters for natural antibodies and associations with specific antibody and mastitis in Canadian Holsteins. J. Dairy Sci. 96:3965-3972. https://doi.org/10.3168/jds.2012-5919.

Urioste, J. I., J. Franzén, and E. Strandberg. 2010. Phenotypic and genetic characterization of novel somatic cell count traits from weekly or monthly observations. J. Dairy Sci. 93:5930-5941. https://doi .org/10.3168/jds.2010-3301.

Urioste, J. I., J. Franzén, J. J. Windig, and E. Strandberg. 2012. Genetic relationships among mastitis and alternative somatic cell count traits in the first 3 lactations of Swedish Holsteins. J. Dairy Sci. 95:3428-3434. https://doi.org/10.3168/jds.2011-4739.

van Dorp, R. T., S. W. Martin, M. M. Shoukri, J. P. Noordhuizen, and J. C. Dekkers. 1999. An epidemiologic study of disease in 32 registered Holstein dairy herds in British Columbia. Can. J. Vet. Res. 63:185-192.

Van Grevenhof, E. M., J. A. M. Van Arendonk, and P. Bijma. 2012. Response to genomic selection: the Bulmer effect and the potential of genomic selection when the number of phenotypic records is limiting. Genet. Sel. Evol. 44:26. https://doi.org/10.1186/1297 $-9686-44-26$

Wagter, L. C., B. A. Mallard, B. N. Wilkie, K. E. Leslie, P. J. Boettcher, and J. C. Dekkers. 2000. A quantitative approach to classifying Holstein cows based on antibody responsiveness and its relationship to peripartum mastitis occurrence. J. Dairy Sci. 83:488-498. https://doi.org/10.3168/jds.S0022-0302(00)74908-3.

Wolf, J., M. Wolfová, and M. Stípková. 2010. A model for the genetic evaluation of number of clinical mastitis cases per lactation in Czech Holstein cows. J. Dairy Sci. 93:1193-1204. https://doi.org/ 10.3168/jds.2009-2443.

Zavadilová, L., M. Štípková, and V. Zink. 2013. Preliminary results from a genetic analysis of clinical mastitis data for Holstein cattle in Czech Republic. Interbull Bull. 47:99-105.

Zwald, N. R., K. A. Weigel, Y. M. Chang, R. D. Welper, and J. S. Clay. 2004a. Genetic selection for health traits using producerrecorded data. I. Incidence rates, heritability estimates, and sire breeding values. J. Dairy Sci. 87:4287-4294. https://doi.org/10 .3168/jds.S0022-0302(04)73573-0.

Zwald, N. R., K. A. Weigel, Y. M. Chang, R. D. Welper, and J. S. Clay. 2004b. Genetic selection for health traits using producer-recorded data. II. Genetic correlations, disease probabilities, and relationships with existing traits. J. Dairy Sci. 87:4295-4302. https://doi .org/10.3168/jds.S0022-0302(04)73574-2. 